\title{
The Legal Framework for the Promotion and Protection of Human Rights in Cameroon by Non-Governmental Organisations
}

\author{
Alvine Longla Boma*
}

\begin{abstract}
Civil Society organisations play key roles in African countries. This is not an exception in the Cameroonian dispensation. Indeed, the existence and operation of civil societies in this jurisdiction is legitimated by a 1990 law allowing the free formation of associations. Even though the state has the primary obligation to promote and protect human rights, there also exists a plethora of associations with the same interest. This paper is motivated by the state's wanton failure in ensuring the enjoyment and fulfilment of the right. For one thing, the state has maintained a stronghold on the Civil Society through legislation which gives public authorities a leverage over human rights defenders. Moreover, an analysis of existing legal and institutional frameworks available to allow human rights non-governmental organisations thrive, leaves much to be desired. Findings reveal that though there are adequate laws and institutions which ensure the creation and functioning of Civil Society organisations in Cameroon, there are also contradictory laws which give the public authority an edge over these organisations and allow them to sanction the activities of some human rights defenders under the guise of maintaining public order. We argue that there should be adequate protection offered to human rights defenders as well as the relaxation of laws permitting public authorities to illegally sanction the activities of relevant non-governmental organisations.
\end{abstract}

\section{A. Introduction}

Human rights are inherent in all human beings, irrespective of nationality, place of residence, sex, national or ethnic origin, colour, religion, language, or any other status. Notwithstanding their theoretical justification, the rights refer to a wide continuum of values or capabilities thought to enhance human agency or protect human interests declared to be universal in character. ${ }^{1}$ They are based on the principle of respect for the individual. The fundamental assumption is that each person is a moral and rational being who deserves

* Associate Professor of Law, University of Buea, Cameroon, Tel: +237 677130835 (Email: alvineboma@yahoo.com).

1 Burns H. Weston, Encyclopaedia Britannica, 2014, https://www.britannica.com/topic/human-rights (accessed on 10/10/2020). 
to be treated with dignity. ${ }^{2}$ Whereas nations or specialized groups enjoy specific rights that apply only to them, human rights apply universally.

The concept of political liberalisation which acted as part of the globalisation process that was unleashed in Africa following the collapse of the Cold War, ${ }^{3}$ led to political reforms being introduced in the majority of countries to promote and protect human rights. ${ }^{4}$ In spite of African countries signing numerous human rights treaties and instituted bodies for the protection and promotion of human rights, there has still been gross violation of rights across Africa and Cameroon in particular. This is generally because there is lack of true democracy in these countries and as such, the bodies created and instituted are not given the freedom and leverage to operate for the purpose for which they were created.

Non-governmental organisations (NGOs) have existed for a long time but were formally recognised by the United Nations in Article 71 of the United Nations Charter of 1945, which states that "the Economic and Social Council may make suitable arrangements for consultation with non-governmental organisations which are concerned with matters within its competence. Such arrangements may be made with international organisations and where appropriate, with national organisations after consultation with the Member state of the United Nations concerned." 5 Under this provision, non-governmental organisations can be granted Consultative Status with the United Nations Economic and Social Council (ECOSOC) and the procedure was initially governed by ECOSOC Resolution 1996/31 of 25 July $1996 .^{6}$

The African Commission on Human and People's Rights is the primary body responsible for human rights protection in the African Continent. ${ }^{7}$ Under the Commission's Rules of Procedure which were adopted in line with Article 45(2) of the African Charter, NGOs can be granted Observer Status by the Commission. They may, through authorised representatives, address the Commission during its public sessions and its subsidiary bodies.

2 United for Human Rights, The Story of Human Rights, 2011, https://www.humanrights.com (accessed on 10/10/2020).

3 The Cold War was a period after the second World War, between 1947 to 1991 which was characterized by tension and arm race between the Eastern Bloc (Soviet Union and its "satellite states") and powers in the Western Bloc (United States of America and others). These two blocs never engaged in an all-out war but provided support to proxy wars which were to their gain. There was growth in authoritarian rule in the Third World countries and failing economies among other things. The end of the Cold War brought a wave of democracy which saw the ousting from power of many of the authoritarian governments and demand for democracy and respect for human rights.

4 Appiagyei-Atua Kwadwo, "Human Rights NGOs and their Role in the Promotion and Protection of Human Rights in Africa", International Journal on Minority and Group Rights, 2002, Vol. 9, No. 3, p. 265.

5 Article 71 of Chapter 10, United Nations Charter 1945.

6 United Nations Economic and Social Council Resolution 288 B (X) was superseded by ECOSOC Resolution 1296 (XLIV) of 25 May 1968. The current terms of reference of the Committee are set out in Resolution 1996/31 of 25 July 1996.

7 Article 30 of the African Charter on Human and People's Rights. 
Moreover, the Commission may consult such NGOs on various issues. ${ }^{8}$ For an NGO to be granted Observer Status with the Commission, the said organisation must work in the field of human rights, declare their financial resources and their objectives must be in consonance with those of the African Union Constitutive Act and the African Charter. ${ }^{9}$

NGOs have been instrumental in the drafting of human rights instruments, in the submission of communications, and the development of the communications procedure of the Commission. ${ }^{10}$ They have also been momentous in bringing the Commission's attention to human rights problems on the continent as well as providing proposed resolutions. In Cameroon, NGOs are governed by Law No. 99/14 of 22 December 1999 and by Law No. 90/53 of 19 December 1990 relating to Freedom of Associations, as amended and supplemented by Law No. 99/11 of 20 July 1999. It is observed that the visibility of Civil Society Organisations in Cameroon came after the institution of these laws. However, the immediate impetus to Civil Society was the economic crisis which resulted in salary cuts within the public service, with the State at the time being the largest employer. ${ }^{11}$ Since the institution of the Law on Freedom of Associations as part of endeavours to enhance the promotion and protection of civil and political rights in Cameroon, there has been considerable increase in the number of NGOs involved in areas such as health, education and training, the environment, women's development, democracy and human rights, rural and urban development, capacity building and research, HIV/AIDS sensitisation and community development, among others. ${ }^{12}$

There are many human rights NGOs in Cameroon that focus on diverse aspects of human rights. They carry out activities across the national territory such as reporting human rights violations, educational campaigns, legal assistance, counselling victims of violations and collecting information vital for the protection of human rights. The National Commission on Human Rights and Freedoms which is the main watch dog on human rights in the country liaises with the relevant organisations in their endeavours. ${ }^{13}$ Thus the Commission collaborates with NGOs mainly through follow up on reports on human rights violations submitted to them by NGOs among other activities.

8 Articles 75 and 76 of the Rules of Procedure of the African Commission on Human and People's Rights.

9 Chapter 1.2, Annex- Criteria for the Granting of and for Maintaining Observer Status with the African Commission on Human and Peoples' Rights 1999.

10 Frans Viljoen, International Human Rights Law in Africa, Oxford, 2007, p. 407.

11 L.N. Fonjong, The Challenges of Nongovernmental Organisations in Anglophone Cameroon, 2007, p. 6.

12 UNDP Survey of NGOs in Cameroon 1997 counted 238 NGOs distributed in the different regions of the country.

13 Article 2 of Law No. 2004/016 of 22 July 2004 to set up the Organisation and Functioning of the National Commission on Human Rights and Freedoms. 


\section{B. The Problem}

The Universal Declaration of Human Rights 1948 (UDHR) and the two enabling instruments of 1966, i.e. the International Covenant on Civil and Political Rights (ICCPR) and the International Covenant on Economic, Social and Cultural Rights (ICESCR), all brought a wave of expectations as concerns the promotion and protection of human rights worldwide. This notwithstanding, there continues to be widespread violations by governments, corporations as well as individuals. Governments who are the primary bodies to ensure the promotion, protection, and fulfilment of human rights in their various States, have ironically been seen over time as the major perpetrators of the violations thereof. As a result, Civil Society organisations have come to the fore and taken up the challenge to assist in this direction.

There is no gainsaying that Cameroon's government has been accused of gross violations of rights especially in areas such as freedom of expression, press and assembly, and the right to life and fair hearing. Examples of government violations include in the cases of individuals such as Albert Mowah Mukong, Pius Njawe, Engo Pierre Desire, Lydienne Yen Eyoum. The violations covered issues such as excessive judicial delays, arbitrary arrests and detention for prolonged periods, in violation of International Conventions especially Article 9 of the UDHR. ${ }^{14}$ Moreover, some of the NGOs have successfully pursued cases against government on behalf of individual victims. For example, the protection of life and property was the issue in the case of Association of Victims of Post Electoral Violence \& Interights $v$. Cameroon, ${ }^{15}$ while delayed judicial proceedings was raised in the case of Open Society Justice Initiative (on behalf of Pius Njawè Noumeni) v. Cameroon. ${ }^{16}$ Cruel and inhumane prison conditions, arbitrary arrests and detention was raised in the case of Ligue Camerounaise des Droits de l'Homme v. Cameroun ${ }^{17}$ amongst others.

In the performance of their role, Human Rights NGOs face challenges which include threats to the lives and families of those working for the organisations. There has also been arbitrary arrests and detention of activists such as, Oben Maxwell ${ }^{18}$ and Abdoulaye Math ${ }^{19}$. Moreover, government has instituted draconian laws which are aimed at monitoring and

14 This Article states that: "No one shall be subjected to arbitrary arrest, detention or exile."

15 Association of Victims of Post Electoral Violence v. Cameroon, Comm. 272/2003, 27 $7^{\text {th }}$ ACHPR AAR Annex III.

16 Open Society Justice Initiative (on behalf of Pius Njawè Noumeni) v. Cameroon, Communication No. 290/04.

17 Ligue Camerounaise Des Droits De l'Homme v. Cameroun, Comm. 65/92, 10th ACHPR AAR Annex X (1996-1997).

18 United States Department of State Bureau of Democracy, Human Rights and Labour, 2017, Country Reports on Human Rights Practices for 2016.

19 Human Rights Watch, World Report, 2000, p. 16. 
disbanding the activities of human rights NGOs. ${ }^{20}$ These include inadequate funding and the lack of proper information and training.

\section{The Origin and Legal Framework of NGOs in Cameroon}

After the end of the Cold War across the world, there was need for rapid development in various countries. This led, especially in the Western nations, to collaboration between States and religious associations and this was especially for the provision of humanitarian aid to less privileged regions. ${ }^{21}$ In Africa, Civil Society and in fact, human rights NGOs are bodies where persons in a community can group themselves to have a collective voice. J.C. Alexander suggests that Civil Society is a "solidary sphere, in which a certain kind of universalizing community comes to be culturally defined and to some degree institutionally enforced." 22

NGOs are one of the most prevalent parts of Civil Society. As stated above, they are regulated in Cameroon by Law No. 90/053 of 19 December 1990 relating to Freedom of Association, amended, and supplemented by Law No. 99/11 of 20 July 1999, Law No. 99/014 of 22 December 1999 to govern Non-Governmental Organisations and Decree No. 2001/150/PM of 13 May 2001 relating to the organisation and functioning of the Technical Commission in charge of NGO activities.

Article 3 of Law No. 99/14 sets out the various areas in which the status of NGO will be granted: legal, economic, social, cultural, health, sports, education, humanitarian sectors or in matters of environmental and human rights protection. It should however be noted that for such status to be granted in any of the sectors, the relevant organisation must be a 'duly declared association or duly authorised foreign association backed by at least 3 (three) years of effective contribution ${ }^{23}$ in any of those sectors mentioned above. The determination of effectiveness is left to the discretion of a 'Commission responsible for the technical study of approval applications and for monitoring the activities of NGOs. ${ }^{24}$ After the status of NGO is granted to an organisation, it acquires legal personality ${ }^{25}$ separate from that of the founder(s) and thus can act in its own name and capacity. The Technical Commission in

20 See the Amnesty International Report 2016/17: The State of the World's Human Rights.

21 Dieudonné Kimaka, Le Cadre Juridique des Organisations Non Gouvernementales au Cameroun, 2009, http://www.mireilletchiako.files.wordpress.com/2015/03/cadre-juridique-des-ong-au-camer oun.pdf\&ved=2ahUKEwimgLOToI3cAhVMJ8AKHUGbD_oQFjAAegQIBBAB\&usg=A0vVaw2 HsCK_g2D98FEBVRW4LLD (accessed on 05/09/2020).

22 Jeffrey C. Alexander, The Civil Sphere, New York, 2006, p. 31.

23 Article 4 of Law No. 99/14 of 22 December 1999 to govern Non-Governmental Organisations.

24 Article 7.

25 Article 9(3). 
charge of NGO activities was created by Article 7 of Law No. 99/14. Nonetheless, this Commission which only came to be in 2001 had granted only $26 \mathrm{NGO}^{26}$ status by 2010 .

\section{Activities of Human Rights NGOs in Cameroon}

There are "numerous associations for human rights which are freely and easily created by declaration." ${ }^{27}$ In Cameroon's South-West Region there are several human rights NGOs. However, according to the list of Associations and NGOs Affiliated to the NCHRF SouthWest Regional Office, only 32 NGOs are affiliated to the Commission. The activities of each human rights NGO are determined by its mission and objectives. However, there are activities which apply across the board for all these organisations such as the collection, verification, and dissemination of information on human rights abuses. Indeed, Forsythe holds the view that globalization has led to "the consolidation of networks of activists, the convergence of strategies, and the global sharing of information and resources." ${ }^{28}$ Local human rights NGOs are better placed to have such information since they are closer to the people than international NGOs.

Local NGOs gather information from various sources such as newspaper articles, eyewitness accounts, examining physical evidence, observing trials, and demonstrations, as well as complaints received from victims of human rights violations. In a bid to collect relevant information for exposing human rights abuses and violations, they "work within a loop of international and domestic ties and feedback loops between NGOs, local social movements, foundations, the media, churches, intellectuals, parts of intergovernmental organisations and branches of governments." ${ }^{29}$ Through these sources, NGOs are able to draw public attention at both the local and international levels on abuses. This information is then used by intergovernmental organisations (IGOs) concerned with human rights protection. As Claude Welch notes, "without the flow of information, documentation, and data from NGOs, the entire human rights implementation system and the UN would come to a halt." 30 Gathering and dissemination of information is part of the protection role of human rights NGOs. Peter R. Baehr adds that "the thematic mechanisms of the UN rely almost

26 Speech delivered by the Chairperson of the NCHRF on Peace, Security and Human Rights in the Central African Region, at the African Sub Regional Meeting of the ACP-UE Joint Parliamentary Assembly, Yaoundé, 28-29 April 2010.

27 Ibid.

28 D.P. Forsythe, The United States and Human Rights: Looking Inward and Outward, University of Nebraska Press, 2000, p. 180.

29 M. Keck and E.S. Kathryn, Activists Beyond Borders: Advocacy Networks in International Politics, New York, 1998, p. 9.

30 Claude Emerson Welch, "Introduction", in: Claude E. Welch (ed.), NGOs and Human Rights: Promise and Performance, University of Pennsylvania Press, 2001, p. 5. 
exclusively upon NGO information." 31 The information collected by these NGOs will be irrelevant if not published or reported.

Reporting is an essential element of the human rights monitoring cycle. Reports constitute a primary tool to record and analyse information, present findings of monitoring and fact-finding activities, express concern about a human rights problem, engage in dialogue and advocate with authorities, as well as propose recommendations for corrective action." 32 For example, local human rights NGOs such as the Centre for Human Rights and Democracy in Africa (CHRDA), collaborates with international NGOs like Amnesty International and the International Crises Group to provide information on human rights violations on the on-going crisis in the North West and South West Regions of the country. These Reports have led the international community to caution the government to investigate and ensure the protection of human rights of its citizens. Unfortunately, this has yet to bear fruits as the situation in this part of the country deteriorates further.

Apart from raising awareness at the international level, the collection, verification, and dissemination of information on violations by NGOs is a major weapon in lobbying governments towards policy change ${ }^{33}$ since such information has the potential to influence lawmakers and politicians towards deriving appropriate policies. This can be in the form of proposals directed to the bodies involved. For example, Human is Right Cameroon and Avocats sans Frontiers Humanitaire du Cameroun address policy proposals for the improvement of prison standards in the Buea Central Prison through the State Council's Chambers to the Minister of Justice. ${ }^{34}$

Furthermore, another activity carried out by human rights NGOs is the mobilisation of shame or "naming and shaming." The terms naming and shaming have been defined as "the collection and dissemination of evidence of human rights violations, with the goal of embarrassing, or shaming, governments into complying." 35 Naming, then, is the public identification by NGOs of evidence of human rights violations by some target (usually a government). Shaming refers to the purpose for which the naming is carried out, which is to cause the individual to desist from such action. ${ }^{36}$ This activity entails the collection of information on violations perpetrated by States and disseminating same with the intention of forcing such nation to comply with human rights instruments and standards. According to Peter Baehr, this strategy is based on the notion that every nation will like to be seen

31 Peter B. Baehr, Non-Governmental Human Rights Organizations in International Relations, Palgrave Macmillan, 2009, p. 37.

32 United Nations, Manual on Human Rights Monitoring.

33 Claude Emerson Welch, 2001, op.cit.

34 Interview with Mr. Chamango Blaise, director of Human is Right Cameroon.

35 S. Cardenas, Conflict and Compliance: State Responses to International Human Rights Pressure, University of Pennsylvania Press, 2000.

36 James C. Franklin, "Human Rights Naming and Shaming: International and Domestic Processes", in: H.R. Friman (ed.), The Politics of Leverage in International Relations, Palgrave Macmillan, 2015, p. 44. 
as civilised and as compliant with human rights protection. ${ }^{37}$ Mobilising shame against States with massive human rights violations is one of the most important roles of NGOs in the African Commission's public sessions. ${ }^{38}$ Although this has been effective to an extent, it has also increasingly been criticized on the ground that it does not exactly change the attitude of governments. ${ }^{39}$

Another important activity of human rights NGOs is the provision of direct services such as ensuring the enforcement of the rights of victims of violations. These NGOs are closer to the people and provide less bureaucratic red tape and overhead" 40 services compared to government bodies such as the National Commission on Human Rights and Freedoms (NCHRF). As grassroots organisations, they are more conversant with the kinds of violations faced by the people and thus can better represent them. ${ }^{41}$ Human is Right Cameroon for example, receives complaints from victims and attempts conciliation and/or relays the case to the institution responsible for such cases such as the Labour Inspectorate, a Welfare Officer, the NCHRF or other relevant authorities. And even in these instances, the NGO also accompanies victims in the process, until the matter is resolved.

Legal counsel is also often offered for free to victims of human rights violations. The Centre for Research, Education and Resource Distribution to Rural and Underprivileged People (CEREDRUP) based in Tiko has been active in the area of provision of direct services especially as concerns violence against women. The NGO carries out home visits to those who have been identified and reports to the relevant quarters. They also track cases of violations across the Tiko Sub-Division and report complaints to the NCHRF and other judicial authorities. ${ }^{42}$

Human Rights NGOs liaise with or have lawyers who sometimes handle pro bono cases for victims. An example is Global Links International which handles pro bono cases on arbitrary arrests and detentions. Moreover, this NGO ensures the release of persons detained illegally and wrongfully. Avocats sans Frontiers Humanitaire du Cameroun champions this area. They identify cases of persons who have been incarcerated illegally as well as those who are impecunious and of vulnerable persons such as women, children and disabled persons. These cases are distributed to the various human rights lawyers who then handle the cases pro bono on behalf of the victims. Direct services are also provided in the form

37 Peter R. Baehr, "Mobilization of the Conscience of Mankind: Conditions of Effectiveness of Human Rights NGOs", in: Erik Denters and Nico Schrijver (eds.), Reflections on International Law from the Low Countries, Martinus Nijhoff, 1998, p. 153.

38 Ibid.

39 See J.C. Franklin, op.cit., p. 44.

40 Maryaan L. Cusimano, Beyond Sovereignty: Issues for a Global Agenda, 4th edition, Cengage Learning, 2010, p. 86.

41 Lina Marcikunte, The Role of Human Rights NGO's: Human Rights Defenders or State Sovereignty Destroyers? Baltic Journal of Law \& Politics, 2011, 4:2, pp. 52-77 (62).

42 Interview with Project Manager for the Centre for Research, Education and Resource Distribution to Rural and Underprivileged People, Tiko. 
of humanitarian aid to victims and to areas where these services are either inadequate or lacking. Avocats sans Frontiers Humanitaire du Cameroun also provides humanitarian aid to prisoners during prison visits.

Again, as a result of their reputation for impartiality, Human Rights NGOs act as conciliators $^{43}$ in mediation processes whether between individuals or between an individual and a corporation. Human is Right Cameroon has acted in this capacity. In 2013, it mediated on land disputed between family members in Tole in the Buea sub-division, where those involved had threatened each other with machetes and death. The organisation mediated as well as educated the members about their legal options. According to the director of Human is Right Cameroon, Mr. Chamango Blaise, there has been a decline in death threats and physical fights over lands in Tole and an increase in the number of complaints lodged at the National Commission, State Counsel Chambers as well as the Office of the Divisional Officer over land disputes in the area.

Another area of activity carried out by Human Rights NGOs is education and sensitisation. Education contributes to the improvement of the status quo, as people learn about their rights and can easily enforce them. In events such as the Prisoners' Rights Project in Buea, Campaigns against gender-based violence in Idenau, Civil Status Registration campaigns in Ekona and others, Human is Right Cameroon educates and sensitises persons not only on their rights and freedoms, but on their obligations as well. In this wise, they organise courses and events such as seminars and roundtables on various human rights topics.

On its part, the Centre for Research, Education and Resource Distribution to Rural and Underprivileged People (CEREDRUP) in Tiko sensitises the population on their rights and freedoms with emphasis on violence against women. They also focus on the rights of people as against the actions of administrative authorities who violate the rights of underprivileged individuals. As such, they educate persons on the functions and operations of the Administrative Court. They also have a program which trains Local Community Agents in Tiko on Accountability and Political Representation. This program which began in 2017 has seen the training of several persons.

Avocats sans Frontiers Humanitaire du Cameroun carries out educational campaigns on the rights of prisoners all over the country in various prisons. They have so far had campaigns in Douala, Yaoundé and Bafoussam. The organisation also holds working sessions with prison administrators in the country. ${ }^{44}$ They educate on women's rights and the rights of those who have been incarcerated illegally and those who have served their terms but are still in prison, a situation which is prevalent in some areas of the country. They are involved

43 Conciliation is an alternative dispute resolution process where an independent third party, the conciliator, helps people in a dispute to identify the disputed issues, develop options, consider alternatives, and try to reach an agreement. See Bryan A. Garner (ed.), Black's Law Dictionary, 2004, p. 307.

44 Interview with Barrister Arrey Collins, National Representative of Avocats sans Frontiers Humanitaire du Cameroun on $10^{\text {th }}$ August 2020. 
in the training of human rights defenders in terms of national and international legal and institutional frameworks on the protection of human rights.

\section{E. Difficulties faced by Human Rights Defenders in Cameroon}

Human rights defenders are those who act "individually and in association with others, to promote and to strive for the protection and realisation of human rights and fundamental freedoms at the national and international levels." 45 Because they assist the State to ensure the full respect of fundamental freedoms, democracy and the rule of law, human rights Civil Society organisations are indispensable. Over the years, the demands for better protection of human rights have heightened. Due to political uprisings, autocratic regimes and other strongholds, human rights defenders are put in a position where they must do more to ensure that States respect their duties. Sometimes however, has led to increasing arbitrary arrests and detentions and extrajudicial killings of the defenders.

The United Nations has adopted the Declaration on the Right and Responsibility of Individuals, Groups and Organs of Society to Promote and Protect Universally Recognized Human Rights and Fundamental Freedoms 1999.46 This Declaration although not binding on States, lays down a framework for the protection of human rights defenders. It covers inter alia, the right to be protected, the right to freedom of assembly, the right to freedom of association, the right to access and communication with international bodies, the right to freedom of opinion and expression, the right to protest, the right to develop and discuss new human rights ideals, the right to an effective remedy, the right to access funding and permissible derogations.

There is no legislation in Cameron which is geared towards the protection of human right defenders. Consequently, they have, and continue to undergo violations in their line of duty. In recent times, there has been massive arrests and detention of several human rights activists. As an Amnesty International Report contends, "human rights defenders, including Civil Society activists and journalists, have continued to be intimidated, harassed, and threatened." 47 Moreover, the Cameroon government adopted an Anti-terrorism Law in $2014 .{ }^{48}$ However, there has been refusal to authorise the holding of conferences and assemblies geared towards human rights sensitisation and discussions like in the case of the NGO, Nouveaux Droits de l'Homme Cameroun which was prevented from organising an activity to discuss the human rights situation in the country in May 2017. The divisional officer for Yaoundé (I) cited disruption of public order as a reason for denial. ${ }^{49}$

45 Article 1, UN Declaration on Human Rights Defenders, 1999.

46 A/RES/53/144, 8 March 1999.

47 Amnesty International. 2017. The State of the World's Human Rights 2016/2017.

48 Law No. 2014/028 of 23 December 2014 on the Suppression of Acts of Terrorism in Cameroon.

49 Submission by Front Line Defenders to the UPR Working Group, October 2017. 
There have also been threats to the lives of several human rights defenders such as Maximilienne Ngo Mbe. In her position as director of Réseau des Défenseurs des Droits de l'Homme de l'Afrique Centrale (REDHAC) she received several death threats in June 2017. The cases of Nkongho Felix Abgor and Fontem Neba is also relevant. They were arrested in January 2017 and charged under the Terrorism Law for being leaders of the now outlawed Cameroon Anglophone Civil Society Consortium which championed the Teachers' and Lawyers' strike actions and subsequent demonstrations.

There are other difficulties faced by these organisations. Leslie Fox notes that NGOs equally lack efficient structures, qualified personnel, adequate funding, and a system of evaluation of their performance. ${ }^{50} \mathrm{~A}$ major difficulty is inadequate and unqualified personnel. Human rights NGOs especially in the rural areas have low workforce and thus find it challenging to carry out their task effectively. As described by Susan Dicklitch, ${ }^{51}$ human rights education NGOs are focused in urban areas and have thus failed to expand their work into the rural areas where there continue to be gross violations. This can partly be attributed to the low level of staffing. Persons are sometimes scared away by the fact that human rights defenders are constantly under threat of detention. This has led to a reduction in the "activities of many NGOs that serve in regions where the institution does not yet have operational branches." 52 Moreover, few staff do master the legal and institutional frameworks for the promotion and protection of human rights. The Rapporteur for the National Commission on Human Rights and Freedoms admitted that many of the NGOs "do not have a good knowledge of the available instruments and the institutions in place and are only driven by passion."

Inadequate funding also prevents some human rights NGOs from functioning effectively. Given this financial restraint, they are not able to achieve their aims. There is usually need for materials for sensitisation, audio-visual campaigns, talk shows among other things which need funds. Also, for those involved with detainees and underprivileged individuals, there is need for funding in order to represent such persons in their cases and proceedings. However, it should also be stated that despite this setback, there are NGOs that receive funding and yet do not deliver on their mission and objectives. There have been situations of donors demanding Reports on work done to no avail. Marc-François Ngwambe notes that "it seems indeed that the creation of associations is often more related to the search for financing than activities to undertake. These organisations seek help, assistance, support,

50 Leslie Fox, A Study of NGOs in the Republic of Cameroon and Côte d'Ivoire, World Bank Occidental and Central Africa Department, Population and Human Resource, 1993, p. 90.

51 S. Dicklitch, "Failed Democratic Transition in Cameroon: A Human Rights Explanation," Human Rights Quarterly 24 (2002), pp. 152-176.

52 National Commission on Human Rights and Freedoms, 2015, Report on the State of Human Rights in 2014, p. 117. 
partnership, collaboration and financing from structures that they deem capable, even before they go operational." 53

Notwithstanding the difficulties, there are institutions and organisations which are out to protect human rights defenders. Even though there are no legislation protecting human rights defenders in Cameroon, the Réseau des Défenseurs des Droits de l' Homme de $l^{\prime}$ Afrique Centrale (REDHAC) sets out to protect the rights of human rights defenders through educating and training as well as representing those who have been illegally arrested and detained. REDHAC has also drawn up a draft Law for the protection of human rights defenders which will be submitted to the Cameroon Parliament for deliberation. The National Commission on Human Rights and Freedoms also seeks to protect human rights defenders whose NGOs are affiliated to the Commission. The Commission seeks for the release of human rights defenders who are illegally detained, as well as trains and educates them. ${ }^{54}$ International mechanisms like the UN Declaration on Human Rights Defenders and Regional Mechanism such as the African Commission on Human and Peoples' Rights which have created specific procedures to deal with the protection of defenders' rights, ${ }^{55}$ have been instrumental in the protection of this group of persons.

\section{F. Relationship between the State of Cameroon and Human Rights NGOs}

\section{An Overview}

Cameroon has made efforts to improve the state of human rights in the country over the years. The State has further created institutions such as the National Commission on $\mathrm{Hu}-$ man Rights and Freedoms, the Department of Human Rights and International Cooperation in the Ministry of Justice and the Inter-Ministerial Committee for the Follow-up of Decisions and/or Recommendations of International and Regional Human Rights Promotion and Protection Mechanisms at the Prime's Minister Office. ${ }^{56}$ Moreover, various government ministries particularly the Ministry in charge of Women's Empowerment and the Family and the Ministry in charge of Social Affairs have been empowered to strengthen the promotion and protection of women's and children's rights and the rights of the disabled. Apart from these, the government has put in place a legal framework to strengthen the state of human rights in the country.

53 M.F. Ngwabe (ed.), Etude Préliminaire sur le Mouvement Associatif au Cameroun, Yaoundé, 1997, p. 6.

54 Interview with Mr. Njome Ekeke Mathias, Rapporteur for the South-West Regional Office of the NCHRF on 8 August 2018.

55 Resolution ACHPR/69 (XXXV) on the Protection of Human Rights Defenders in Africa and Resolution ACHPR/Res. 199 (XXXXII) 07 on the Situation of Human Rights Defenders in Africa. Available at www.achpr.org/sessions/50th/resolutions/196.

56 Ministry of Justice, 2014, National Action Plan for the Promotion and Protection of Human Rights in Cameroon 2015-2019, p. 4. 
The importance of cooperation with Civil Society cannot be overemphasised. The Department of Human Rights and International Cooperation created by Decree No. 2005/122 of 15 April 2005 on the Organization of the Ministry of Justice is required to liaise, inter alia, with NGOs. ${ }^{57}$ The National Commission on Human Rights and Freedoms as well, has been enabled with the capacity to work where necessary, with non-governmental organisations in the field of human rights. ${ }^{58}$

\section{The Cameroon National Commission on Human Rights and Freedoms (NCHRF)}

The Commission was established by Law No. 2004/16 of 22 July 2004, replacing the National Committee on Human Rights and Freedoms set up by Decree No. 90/1459 of 8 November 1990. It is an "independent institution for consultation, monitoring, evaluation, dialogue, concerted action, promotion and protection in the domain of human rights." 59

In line with the Paris Principles, ${ }^{60}$ the Commission has cooperated with NGOs in carrying out sensitisation campaigns, receiving complaints on violations from these Organisations, training members of NGOs etc. Working with NGOs in receiving and processing complaints has proven to be a positive result of collaboration. These NGOs have been instrumental in bringing several cases to the attention of the Commission which has in turn witnessed an increase in the level of protection of human rights in the country. ${ }^{61}$ They have so far served as an access point for the Commission to reach out and meet the needs of the population including in the rural areas. ${ }^{62}$

As of 2014, the Commission had a total number of 120 workers serving a population of more than 21 million persons, "which gives a ratio of 179,167 persons per 1 NCHRF staff." ${ }^{\circ 3}$ It has only one office in each Region which makes it almost impossible for persons

57 Article 56(1) para. 4 of Decree No. 2005/122 of 15 April 2005 on the Organization of the Ministry of Justice.

58 Article 2 para. 9 of Law No. 2004/16 of 22 July 2004 to set up the National Commission on Human Rights and Freedoms (NCHRF).

59 Article 1 (2) of Law No. 2004/16 of 22 July 2004 to set up the National Commission on Human Rights and Freedoms.

60 Principles relating to the Status of National Institutions (The Paris Principles.) General Assembly Resolution 48/134 of 20 December 1993. The Principles on the Methods of Operation provides in Paragraph (g) that "In view of the fundamental role played by the non-governmental organizations in expanding the work of the national institutions, develop relations with the non-governmental organizations devoted to promoting and protecting human rights, to economic and social development, to combating racism, to protecting particularly vulnerable groups (especially children, migrant workers, refugees, physically and mentally disabled persons) or to specialized areas."

61 Interview with Mr. Njome Ekeke Mathias, Rapporteur for the South-West Regional Office of the NCHRF on 8 August 2018.

62 See NCHRF 2017 Activity Report.

63 United Nations Development Programme (UNDP) 2016. Study on the State of National Human Rights Institutions (NHRIs) in Africa, p. 53. 
in rural and remote areas to benefit from its activities and services. As such, organisations which have access to the grassroots have been influential.

As part of its collaborative efforts with NGOs, the Commission organises activities for the promotion and protection of human rights across the national territory. In his opening address at the $20^{\text {th }}$ Ordinary Session of the NCHRF, the Chairperson of the National Commission on Human Rights and Freedoms (NCHRF), Cameroon, stated that there is a continuous increase in the number of complaints which the Commission handles throughout the national territory, ${ }^{64}$ a majority of which are from both local and international NGOs. ${ }^{65}$ The Commission conducts awareness campaigns and seminars with NGOs, such as the seminar on the Generalisation of the Teaching of Human Rights in Primary and Secondary Schools in Cameroon in collaboration with Réseau Camerounais des Organisations des Droits de l'Homme (RECODH), Cameroon Youths and Students Forum for Peace (CAMYOSFOP), including participants from the Ministries of Basic and Secondary Education and the United Nations Development Programme (UNDP). In a Capacity Building Workshop on the Rights of Persons with Disability organised by the Commission on 27 June 2016, the NCHRF educated stakeholders on the role of NGOs in protecting persons with disabilities including the legal and institutional frameworks available. In a bid to improve cooperation with NGOs, one of the Resolutions at the $21^{\text {st }}$ Ordinary Session of the Commission was, "to ensure that all subsequent Annual Reports of the Commission on the state of human rights should be validated by Civil Society organisations in the domain of human rights."

\section{The Ministry of Women's Empowerment and the Family (South-West Regional Delegation)}

This Ministry was created by Decree No. 2004/320 of December 2004 to organize the Government of Cameroon and advocates for the preservation of the woman and the girl child within the family. Its role is to empower the woman and the family socially, economically, politically, culturally, and otherwise. Also, it educates on gender-based violence and discriminatory practices that target women. As relates to cooperation with Civil Society organisations, the Division for Studies, Planning and Cooperation has as one of its responsibilities to foster "national and international cooperation with bodies for the advancement of women, the family and children's rights." 66 As part of fulfilling the missions of the

64 National Commission on Human Rights and Freedoms 2016 Activity Report, p. 10.

65 Human Rights Watch, Protectors or Pretenders? Government Human Rights Commissions in Africa, 2001, https://www.hrw.org/reports/2001/africa/cameroon/cameroon5.html\#P1121_254638 (accessed on 20/03/2019).

$66 \mathrm{http}: / / \mathrm{www} \cdot \mathrm{minproff} . \mathrm{cm} /$ the-ministry/adminitration-centrale/directions-et-divisions/division-des-et udes-de-la-planification-et-cooperation (accessed on 29/07/2020). 
Ministry, the South-West Regional Delegation cooperates with close to 31 NGOs and other women's groups in the region for the promotion of women's rights. ${ }^{67}$

With the support of national and international partners, the Ministry of Women's Empowerment and the Family has elaborated and adopted the National Plan of Action for the Integration of Women in Development, with focus on seven out of the twelve priority areas retained at the Beijing Conference. ${ }^{68}$ These areas include: improving the living standards and the legal status of women, including women in decision-making, fighting against violence on women, educating young girls, improving the living conditions of women and, improving the institutional framework of and the protection of women by the courts.

Due to budgetary constraints most of the projects are intensified and carried out in collaboration with the Civil Society. These organisations facilitate the work by relaying cases of violence against women and the girl child to the Delegation, which then handles the cases with its focal points in the judiciary and health sectors as well as with the NGOs. In addition to this, through these partnerships, the Delegation has been able to secure financial and legal aid for female victims and survivors of violence. Human rights associations such as Reach Out Cameroon, Martin Luther King Memorial Foundation (LUKMEF) work with the Delegation to provide loans and other financial aids to survivors of violations, widows, and other impecunious women to further the empowerment of women in the community. Some NGOs such as International Federation of Female Lawyers Cameroon (FIDA) also handles pro bono cases on behalf of survivors of violations.

In the area of human rights promotion, the Regional Delegation organises in collaboration with NGOs, campaigns for the promotion of rights of women, children as well as fight against gender-based violence especially during certain commemorative days ${ }^{69}$ For example, during International Women's Day commemorated on the $8^{\text {th }}$ of March annually, the Regional Delegation teams up with Reach Out Cameroon, to give talks and carry out free screenings for HIV/AIDS. Radio programmes, flyers and slogans on matters such as the right to inheritance, widows' rights, disadvantages of gender-based violence etc, are distributed.

67 Interview with Chief of Service for Statistics at the South-West Regional Delegation of the Ministry of Women's Empowerment and the Family.

68 Convention on the Elimination of All Forms of Discrimination against Women, 1979.

69 The Ministry organises and launches various sensitisation campaigns during such days as International Day against Female Genital Mutilation on 6 February; International Women's Day on 8 March; International Day of the Family on 16 June; International Day of Widows on 23 June; Day of the African Woman on 31 July; International Day of the Girl Child on 11 October; International Day of the Rural Woman on 15 October; and 16 Days of Activism against violence towards women and girls in Cameroon organised between 25 November to 10 December. 


\section{Challenges to Cooperation}

Despite the desire of government and its institutions for effective cooperation with Civil Society regarding the promotion and protection of human rights, there remains much to be done due to some impediments existing in some instruments such as Law No. 90/54 of 19 December 1990 relating to the Maintenance of Law and Order, Law No. 90/55 of 19 December 1990 to Lay Down Regulations Governing Public Meetings and Processions.

Sections 3(2) and 6 (1) of Law No. 90/54 of 19 December 1990 to Lay Down Regulations Governing Public Meetings and Processions requires every public meeting, public processions, demonstrations, parades, marches, and rallies to be declared through the district head or the sub-divisional officer. However, Section 8(2) provides that if the administrator "deems that the planned procession is likely to seriously disturb the peace, he may, as the case may be: schedule another venue or route for it; prohibit it by Order which he shall immediately notify to the signatory of the declaration at the elected domicile." This in effect gives the administrator the discretion whether to allow a public meeting, etc or not. This can defeat the purpose of the laws on Freedom of Association and Assembly.

On its part, Section 2 of Law No. 90/55 of 19 December 1990 Relating to the Maintenance of Law and Order provides that "administrative authorities may, at all times and depending on the circumstances, take the following measures within the framework of operations for the maintenance of law and order...control the movement of persons and goods." This has inevitably led to the banning or suspension of public meetings, rallies, demonstrations for the demand of certain rights from government.

A drawback in cooperation also stems from the fact that some Civil Society organisations are unorganised. There is equally an absence of synergy of Civil Society organisations as a means of liaising with government institutions. Some human rights associations are not affiliated to the National Commission on Human Rights and Freedoms. As such, the Commission is not able to protect the human rights defenders who are not affiliated to it. Consequently, most of the associations are not apprised with the institutional and legal frameworks available for the protection of victims. This in effect hampers the degree of protection which can be offered to victims.

\section{Conclusion}

The recognition of NGOs by the UN through Article 71 of the UN Charter has led to the growth in influence of Civil Society organisations worldwide. The impact this sector has had on societies is undeniable. The identification of the significant role non-governmental organisations play in various fields has led various organisations such as the UN, its subsidiary specialised bodies, African Union and the European Union to include them in their functioning. This is a precursor to the fact that the sector is relevant to the development of those areas in which they operate. The assumption here, therefore, is that the 
obligation of States to promote and protect human rights cannot be fully achieved without the involvement of human rights NGOs.

With the growth of human rights NGOs in Cameroon, this sector has been vital in monitoring and reporting violations which has in turn, led to reforms. Human rights popularisation through education and sensitisation can be credited largely to the activities of NGOs. It is hoped that this spirit will not wane, but that NGOs double their efforts in this noble direction. 